\title{
Cincuenta años de la revista "Útimos Avances en Materiales de Construcción"
}

\section{Fiftieth anniversary of the journal "Últimos Avances en Materiales de Construcción"}

Prof.Dr.JOSÉ CALLEJA

Asesor de IECA

Fecha de recepción: 21-VI-2001

ESPAÑA

\section{RESUMEN}

El propósito del autor es presentar una visión panorámica histórica del nacimiento, crecimiento y desarrollo a lo largo de cincuenta años de la revista MATERIALES DE CONSTRUCCIÓN, principalmente dedicada a temas de cemento y hormigón.

Esto se ha tratado de llevar a cabo en la presente exposición teniendo en cuenta cuatro periodos de dicha vida: "Prehistoria" (Antecedentes), "Protohistoria" (La Revista), relativa a Los Cien Primeros Números de la misma, "Historia Moderna", en la que se trata de sus Cien Segundos Números, e "Historia Contemporánea", en la cual se describe brevemente el estado actual de la Revista.

La descripción ha sido realizada con un propósito analitico y crítico, poniendo el énfasis en toda clase de aspectos.

\section{SUMMARY}

The aim of the author is to present an historical survey of the birth, growth and development along the fifty years of the life of the scientific and technical magazine MATERIALES DE CONSTRUCCIÓN, mainly devoted to cement and concrete matters.

This has been intended in the present paper taking into account four periods of the mentioned life: "Prehistory" (Antecedents), "Protohistory". (The Journal) referred to The First Hundred Numbers of the Journal, "Modern History" dealing with The Second Hundred Numbers of it, and "Contemporary History", in which the present state of the Journal is described in brief.

The description has been carried out with an analytical and critical purpose, giving emphasis in it to all kind of aspects.

\section{O. PROEMIO}

Con motivo de la celebración del Cincuentenario de una Revista Técnica que lleva por título el que encabeza este trabajo, y que andando el tiempo y por inversión de los términos se tituló: "MATERIALES DE CONSTRUCCIÓN: ÚLTIMOS AVANCES", en la actualidad simplemente "MATERIALES DE CONSTRUCCIÓN", editada antaño por el Instituto Técnico de la Construcción y del Cemento (ITCC) y hogaño por el llamado Instituto de Ciencias de la Construcción "Eduardo Torroja" (ICCET), se me ha pedido que colabore en dicha celebración.

¿En qué forma? Pues aportando un escrito para un número extraordinario de la misma, el doble 263-264,

\section{PROEM}

For the event of celebrating the Fiftieth Anniversary of the publication of our Journal, once called "MATERIALESDE CONSTRUCCIÓN: ÚLTIMOS AVANCES"-BUILDINGMATERIALS:MOST RECENT ADVANCES-, now just "MATERIALES DE CONSTRUCCIÓN", and published by the Instituto Técnico de la Construcción y del Cemento (ITCC), which became later Instituto de Ciencias de la Construcción 'Eduardo Torroja' (ICCET), I have been invited to collaborate in such celebration.

How could I collaborate? Certainly writing a memorabilia to be published in the double issue of 
que la actual Dirección de dicha Revista, a cargo de la Dra. Francisca PUERTAS, piensa editar en tal ocasión con carácter conmemorativo.

Petición que he acogido con agrado y con agobio. Con agrado, pues no en balde he sido colaborador sobre temas de cemento y hormigón en dicha Revista desde sus más remotos orígenes, allá por los últimos años 40 de los pasados siglo y milenio, y durante varios lustros. $\mathrm{Y}$ con agobio puesto que, por ser un pésimo jubilado, acepto más compromisos de trabajo de los que sería menester.

Por cierto, permítaseme y perdóneseme que, a ratos; me exprese en primera persona, cosa que creo hacer por vez primera, pero que en esta ocasión se justifica por el tema que voy a tratar; $y$, sobre todo, por cómo lo voy a hacer en cuanto a la parte de enfoque particular y personal que le voy a dar.

Es curioso que quien me solicitó esta colaboración, la propia Dra. PUERTAS, me sugirió incluso el tema: "Hombre, me vino a decir, puesto que últimamente vienes ocupándote de la Normalización de los Cementos a escala nacional e internacional, podrías escribir algo sobre ello". A lo cual desde aquí respondo: "Puedo, pero no quiero. Estoy un tanto aburrido de lo monocorde de ese tema y prefiero hacerlo sobre algo que, dadas las circunstancias de mi edad y de mi, todavía, excelente memoria documentación aparte, pocas personas podrían hacer, por no haberlo vivido. Voy a escribir sobre la prehistoria y la protohistoria de la Revista, que muy pocos si alguno conoce y recuerda en su totalidad". Y a ello voy, no sin antes aclarar que mi intención es hacer destacar la contribución que a la "originalidad" de la Revista aportó el "estamento" de profesionales químicos Doctores y Licenciados que entonces, de una forma u otra, formábamos parte del ITCC.

\section{PREHISTORIA (ANTECEDENTES)}

En 1947, y en el seno del Patronato "Juan de la Cierva" de Investigación Técnica, del Consejo Superior de Investigaciones Científicas (CSIC) se creó, a determinadas instancias de las que hablo en otros lugares (1)(2), el INSTITUTO DEL CEMENTO.

\section{Lo dirigió Don Félix GONZÁLEZ GUTIÉRREZ, Ingeniero del Ejército, de la rama de Construcción, Coronel Director que fue del Laboratorio de Ingenieros del Ejército y Delegado del Gobierno en la Industria del Cemento, cuando tal Delegación existía. Persona excelente, gran conocedor del Sector Cementero con quien tuve el privilegio de mantener un trato directo y cordial.}

the Journal (Number 263-264) that Francisca PUERTAS, the Director, intends to publish to honour this celebration.

I am pleased to do so, and at the same time overwhelmed. Pleased, because I have been collaborating with the Journal in all subjects concerning cement and concrete from its earlier steps, in the 40s of last century and millennium; overwhelmed since being already retired, I still load more work than I should.

First of all I have to beg your pardon for sometimes I express myself in first person. Surely I ought to be excused on account of the personal focus I am giving to my writing.

Surprisingly, the person who asked me for collaboration, also suggested the subject: "Look, -did she say- since lately you are involved in Cement Standards at national and international level, you might write something about". "I can but I don't want" was my sharp reply, "it is tiresome to be all the time turning around the same subject, I like better, now, since I have lived long enough, and also my memory is good enough, to write about the origins and history of our Journal, that only few people know or remember totally". And here I am, ready to start, but first I have to state how much of the "peculiarity" of the Journal is owed to the professionals we were, at that time, the core of the ITCC.

\section{PREHISTORY (ANTECEDENTS)}

In 1947, under the auspices of the "Patronato "Juan de la Cierva" of Technical Research-Higher Council of Scientific Research (CSIC)-, and attending requests of professionals further mentioned (1) (2), the INSTITUTO DEL CEMENTO-CEMENTINSTITUTE-was founded.

The Manager-Director, Mr. Félix GONZÁLEZ GUTIÉRREZ, was a Colonel Engineer of the Army in the branch of Construction, Chief of the Engineering Laboratory of the Army, and Delegate of the Government in the Cement Industry. An excellent person, very competent in cement matters, whose acquaintance makes consider myself a privileged fellow. 
Formaban parte de aquel Instituto, sito en un primer piso del número 11 de la calle Gaztambide de Madrid, él como Director, un Secretario, dos mecanógrafas una de ellas Enriqueta GARCÍA PIÑUELA, hasta hace "poco" tiempo miembro del ICCET y hoy jubilada, un ordenanza el siempre recordado José SÁNCHEZ RUEDA ("SÁNCHEZ”), un Licenciado en Ciencias Químicas, el inolvidable y querido "Don Pablo" por antonomasia GARCÍA DEPAREDES GAIBROIS, procedente del Laboratorio de Ingenieros del Ejército, del cual formaba parte, como otros, como "personal civil".

Y allí fui a pasar yo como "becario", por circunstancias que en otro lugar describo (1), siendo ya Doctor y Colaborador Científico por oposición (el único de todo el futuro ITCC) de la División de Ciencias de CSIC en el Instituto de Química Física "Antonio de Gregorio Rocasolano".

Pero, a lo que voy. Don Pablo se ocupaba de la "Información Bibliográfica", para lo cual preparaba una serie de "Fichas Técnicas" con el formato y la presentación de tales, en las cuales se incluían resúmenes de trabajos sobre CEMENTO -el Instituto era sólo "Del Cemento"- que aparecían en las revistas extranjeras -pocas-, a las cuales podía tener acceso; a veces tenía que conformarse con los resúmenes que encontraba en el "Chemical Abstracts". Pues bien, estas fichas y el sistema para su preparación y presentación fueron los que dieron la pauta para la elaboración de los primeros números de la Revista "ÚLTIMOS AVANCES ENMATERIALESDE CONSTRUCCIÓN”, en los cuales no se hacía sino recoger, una detrás de otra, las fichas de marras o sus equivalentes posteriores, en un principio siempre a cargo, por mor de la inercia, de Don Pablo GARCÍA DE PAREDĖ.

Hasta aquí la "Prehistoria".

\section{PROTOHISTORIA (LA REVISTA)}

La Revista como tal se publicó ya por el INSTITUTO TÉCNICODELA CONSTRUCCIÓN Y DEL CEMENTO (ITCC), resultante de la fusión del ya citado INSTITUTO DEL CEMENTO con el llamado INSTITUTOTÉCNICODELACONSTRUCCIÓNY EDIFICACIÓN, privado y datante de 1934, el cual se integró en el Patronato "Juan de la Cierva" también en aquellas fechas, lo que propició en 1949 la fusión de ambos -o más bien la absorción del primero por el segundo-, con los consiguientes cambios económicos, administrativos y de dirección, y consiguientemente en la orientación del nuevo Centro. Esta orientación fue sin duda muy distinta de la que el INSTITUTO DEL
The staff of this Institute, which at that time was located in Madrid, Gaztambide, 11, was constituted by: himself as Director, two typewriters (one of them Enriqueta GARCÍA PINUUELA, today a retiree), the well remembered janitor José SANCHEZ RUEDA, the unforgettable "Pablo" GARCÍA DE PAREDES GAIBROIS, a BA. in Chemistry, also from the Engineering Laboratory of the Army, in which he acted as "civil" personnel.

Different circumstances (1) made me drop over there, having been granted with a scholarship. I already was a Ph.D. and a Scientific Researcher-once I had overcome the proficiency test of the CSIC Sciences Division at the Institute of Physical Chemistry "Antonio de Gregorio Rocasolano"

But let's go back to "Pablo" who was in charge of the "Bibliographical Information". For this purpose he used to prepare "Technical Cards" were he translated abstracts of works related to CEMENT from the few foreign journals available; sometimes he would resent not to find many abstracts, but would be happy to get, at least, those from "Chemical Abstracts". These cards and the system for their preparation and presentation served as a base for the early numbers of the Journal "ÚLTIMOSAVANCESENMATERIALESDE CONSTRUCCIÓN"'-LAST ADVANCESON CONSTRUCTION MATERIALS-, and still Pablo GARCÍA DE PAREDES was in charge, following a kind of inertia, doing nothing but neatly collecting and classifying cards.

This is the end of the Prehistory.

\section{PROTOHISTORY (THE JOURNAL)}

The Journal was published as such by the INSTITUTO TÉCNICODELA CONSTRUCCIÓNY DEL CEMENTO(ITCC)-TECHNICAL INSTITUTE FOR CONSTRUCTION AND CEMENT. This Institute was the result of the fusion of INSTITUTO DEL CEMENTO with INSTITUTO TÉCNICODE LA CONSTRUCCÍON YEDIFICACIÓN-TECHNICAL INSTITUTE FORBUILDING ANDCONSTRUCTIONwhich was a private institution created in 1934. The new Institute was absorbed by the Patronato "Juan de la Cierva" with the subsequent changes needed for the new orientation of the Center. The orientation was now very different from this of the INSTITUTO 
CEMENTO, a semejanza de sus homólogos el CERILH francés -Centre d'Études et de Recherches de l'Industrie des Liants Hydrauliques-, o el alemán -Forschungsinstitut der Zementindustrie- de la Unión de Fabricantes Alemanes de Cemento: Verein Deutscher Zementwerke (VDZ), ya entonces existentes, hubiera tenido, al ser "monográfico" o muy prioritariamente "cementero".

Se trata de celebrar ahora, dentro del año 2001, el Cincuenta Aniversario de la creación de la Revista, lo cual querría decir que ésta nació en 1951. Sin embargo, éste es un extremo difícil de comprobar "documentalmente", pues se da la peculiar circunstancia de que los primeros -y, como se verá, aún "segundos"- ejemplares de la Revista iban sucesivamente numerados, ipero carecían de fecha! Asimismo, tampoco se señalaba en ellos periodicidad alguna. El único dato orientativo que se puede aportar al respecto es el de que el Número 14, por un azar, lleva fecha de octubre de 1950, lo que hace probable que la Revista naciese dicho año, o incluso en 1949, pero no posteriormente. $Y$ dado que en el primer número se hacía referencia a trabajos publicados en 1949, ya no cabe duda de que la Revista nació en dicho año, con lo cual su Cincuentenario se cumplió en 1999.

El Número 1 carecía también de índice, pero en su portada, de cartulina a dos colores en franjas verticales, se señalaba que era de circulación limitada, pudiéndose apreciar por la diferencia de tamaño de letra entre "ÚLTIMOS AVANCES" y "Materiales de Construcción", la idea que se quería transmitir acerca de qué se consideraba como sustantivo y qué como adjetivo del contenido de la Revista. Por no se sabe qué circunstancia, ni en el Archivo del ICCET, ni en mi colección personal, ni en la particular y propia del Prof. Dr. Francisco SORIA, regalada por éste en su día a la Dra. María Isabel SÁNCHEZ DE ROJAS, actual miembro del ICCET, figura el original del Número 1, sino sendas copias del mismo, como la que muestra la Figura 1. El aspecto real externo del primer número es el de la Figura 2, correspondiente al número segundo de la Revista. (Entre paréntesis diré que siempre fueron muy peregrinas las altisonantes calificaciones dadas a las actividades del Instituto. Así, por ejemplo, los Cursos de Microscopía del Clínker, dados por el Prof. Dr. Buenaventura TAVASCI, en el año 50, fueron Cursos de "ALTA" especialización en Cemento; los CEMCO fueron y son Cursos de Estudios

"MAYORES" de Construcción y los Avances en Materiales de Construcción fueron durante mucho tiempo "ÚLTIMOS").

Me apresuro a señalar que desde el Número 1 hasta el 79 inclusive de la Revista, la tirada "limitada" se hacía en multicopista; la tirada impresa no comenzó sino a partir del 80.
DEL CEMENTO, which was intended to be a similar institution to CERILH, the French Centre d'Études et de Recherches de L'Industrie des Liants

Hydrauliques, or the Forschungsinstitut der Zementindustrie of the Union of German Cement Manufacturers (VDZ), for it should have been "monographic" or with a marked priority for "cement".

In this year 2001, our deal is to celebrate the Fiftieth Anniversary of its birth, which would mean that the starting date was 1951. However this is difficult to prove since the peculiar circumstance that first number of the Journal and even the second were numbered, but not dated! Moreover, they did not indicate any periodicity. The only evidence available is that Number 14, by chance, shows the date of october 1950 which means this could be its birth-date, or maybe 1949, since it refers to some articles published that year; therefore the fiftieth anniversary could have been 1999.

In addition there was no Index, just a vertically striped cardboard cover indicated it was a limited edition, and the difference in size within the title: "ÚLTIMOS AVANCES" and "Materiales de Construccion" indicated which of the two contents was considered the most relevant. In another hand no track has been found in the ICCET Archives, either in my personal collection, or in Prof. Francisco SORIA's collection (now in Dra. Isabel SÁNCHEZ DE ROJAS - a member of the ICCETpossession), Number 1 does not appear but just copies of it as that shown in Figure 1. The true external aspect of first number is the one appearing in Figure 2. (by the way, I will quote the emphatic way the Journal uses to describe activities of the Institute, so, courses of Clinker microscopy, by Prof. Dr. B.Tavasci

-1950- were of "HIGH" cement specialization, CEMCO courses were "MAJOR" Studies on Construction, and Advances on Construction Materials were for a long time "THE MOST RECENT").

Also I have to state that from Number 1 until number 79 those "limited" issues were made with a duplicating-machine; printing was only used from number 80 on. 


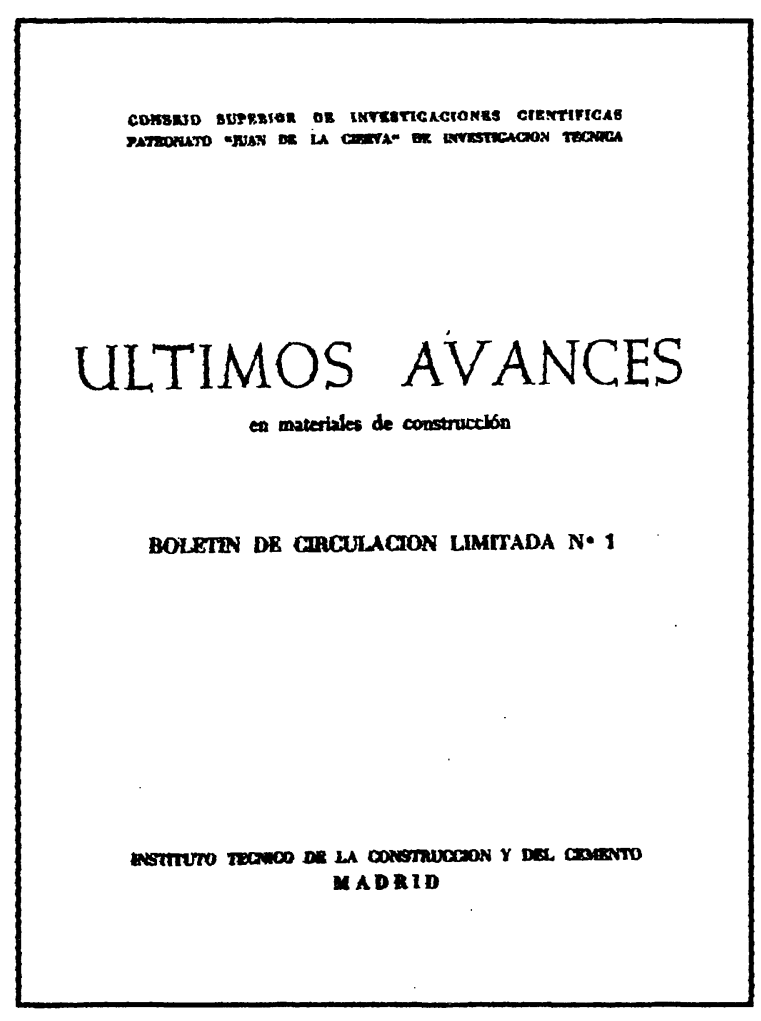

Figura 1.

Figure 1.
La Dirección "artística" por así decir, tanto de "ÚLTIMOS AVANCES" como de "INFORMES DE LA CONSTRUCCIÓN" -otra de las revistas del ITCC, cuyo cincuentenario se celebró ya en 1998-, de las Monografrías; Manuales, Normas, Cuadernos de Investigación, etc., es decir, de las "Publicaciones" en general del Instituto, se llevó siempre a cabo por parte de Arquitectos "de la casa". Recuérdense en justicia, tal vez con algún otro, los nombres de Jesús MARTÍNEZCABRERA, Fernando CASSINELLO PÉREZ y Vicente MAS SARRIÓ. Después la cosa fue distinta, al menos por lo que a "ÚLTIMOS AVANCES” se refiere. El diseño, delineación, montaje, etc., es decir, lo equivalente a lo que ahora se llama "maquetación" corría a cargo de un eficaz equipo compuesto por el Jefe del Departamento de Publicaciones, Julio GUEZALA, auxiliado por Fernando IGLESIAS ("Panano"), RamónIRIGOYEN como delineante, María MARTÍNEZMALLÉN ("Maruchi") como correctora de pruebas.

Pero los resúmenes y extractos de los trabajos publicados en revistas extranjeras, aparte de los muy primeros, de los que se ocupaba, como queda dicho, GARCÍA DE PAREDES, estuvieron a cargo de químicos: sucesivamente Luis SASTRE CID y Serafín FRAGA SÁNCHEZ, ambos circunstancialmente alumnos míos de Bachillerato, cuando yo cursaba la Licenciatura de Ciencias Químicas, allá por los primeros años 40. Creo recordar que, en alguna

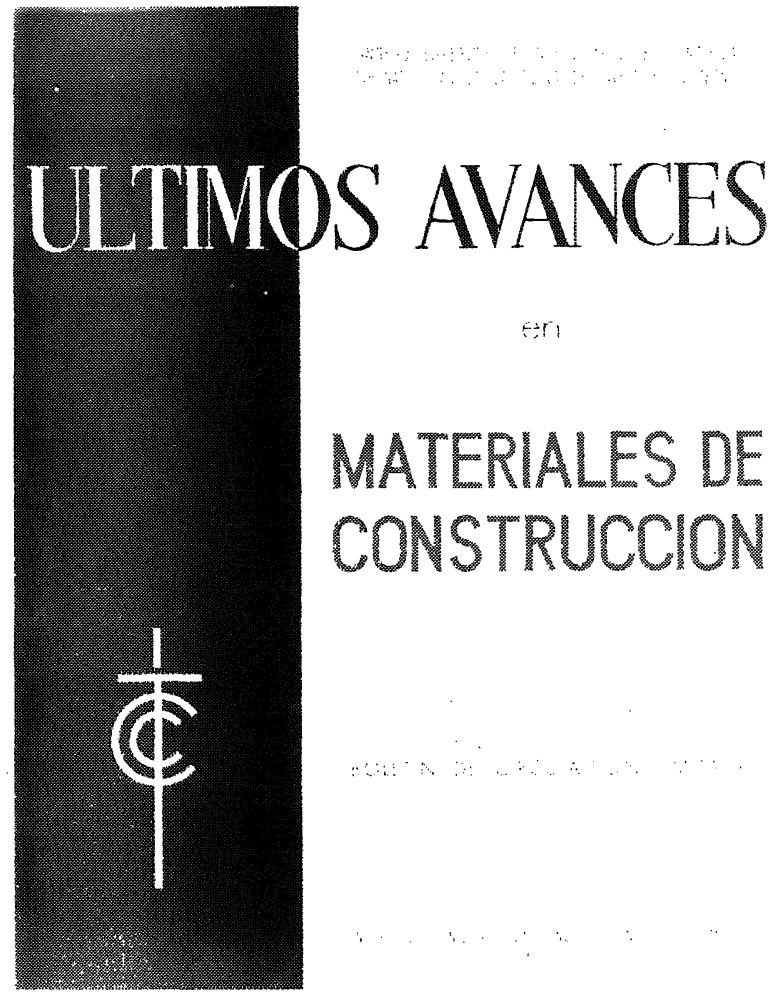

Figura 2.

Figure 2.

"Artistic" supervision of Monographs, Handbooks, Research reports, etc. of both journals "ÚLTIMOS AVANCES" and INFORMES DE LA CONSTRUCCIÓN -REPORTS ON CONSTRUCTION-(the latter had his fiftieth anniversary in 1998) was handled by "home" Architects. I do remember names as Jesús MARTÍNEZ CABRERA, Fernando CASSINELLO and Vicente MAS SARRIÓ. Further changes put in charge a team for taking care of what is called now "the making" in Publishing Department with Julio GUEZALA helped by Fernando IGLESIAS (Panano), Ramón IRIGOYEN as draughtsmain and Maria MARTÍNEZ MALLÉN (Maruchi) as proof corrector

Except for the very beginning, it was Luis SASTRE $C I D$, and later, Serafin FRAGA SÁNCHEZ -both pupils of mine while I was about to pass my Ba. in Chemistry, back in the 40's,- who were in charge of collecting abstracts from foreign journals, and I also 
circunstancia y medida, participaron también en la labor de los resúmenes los, tiempo después, Profs. Drs. José María TOBIO SILLERO y Demetrio GASPAR TEBAR, y hasta tal vez yo mismo. A FRAGA le sucedió como se dirá más adelante, el Aparejador Carlos SÁNCHEZCASTRO.

\subsection{Los cien primeros números de la revista}

Del número 1 ya se ha dicho algo en lo que precede. Incluía como encarte en imprenta y como página 0 una hoja en la que se daba cuenta de la constitución del Consejo Técnico-Administrativo y Dirección del Instituto y de las actividades que se asignaba el Centro (Figura 3). Un dato que al respecto podía llamar la atención es que de los nueve consejeros, incluido el Presidente del Consejo, sólo tres -un tercio- eran "cementeros" (Don Marcelo LUMBLER, Don Patricio PALOMAR y Don Julián REZOLA, ninguno de ellos Presidente), siendo así que los recursos financieros para el sostenimiento del "nuevo" Instituto provenían, prácticamente en exclusiva, del INSTITUTO DEL CEMENTO, a través de una tasa sobre el precio del tonelaje de cemento producido en España y vendido en el mercado nacional.

Una anécdota, hoy: uno de los trabajos reseñados en dicho Número 1 era de los autores rusos

KONOVALEV y SKUE, -figuraban así, sin iniciales-, llevaba por título "CÓMO ACELERAR LA CLINKERIZACIÓNMEDIANTEADICIÓNDE ESPATO FLUOR A LA MEZCLA DE CRUDOS"y había sido publicado en la revista soviética TSEMENT y recensado en los CHEMICAL ABSTRACTS. Sin duda que este dato les ha de sonar a algunos de los actuales investigadores del ICCET quienes, andando el tiempo y poco ha, se han ocupado con éxito, al cabo de los muchos años transcurridos -el trabajo de referencia databa de 1949-, del mismo tema, con visos de modernidad.

Y una curiosidad: el Número 1 contenía 48 páginas, su formato era de $28 \times 22 \mathrm{~cm}$, y en sus reseñas no se incluían gráficos ni figuras, pero, eso sí, se dejaban libres y en blanco los espacios correspondientes a los mismos, como se muestra en su página 23 , entre otras (Figura 4).

Los números siguientes de la Revista fueron del mismo corte aunque, a partir del Número 2 ya con índices, en los cuales figuraban únicamente los títulos de los trabajos reseñados, pero no los nombres de sus autores, remitidos a las páginas correspondientes. En el segundo y sucesivos aparecían ya figuras, al final de los fascículos, en hojas de papel cuché y de una forma muy "sui generis" con numeración sucesiva todas las de cada número, aunque pertenecieran a trabajos remember at this task Professors: José Maria TOBIO SILLERO and Demetrio GASPAR TEBAR, and even myself. Later on Carlos SÁNCHEZ CASTRO replaced FRAGA.

\subsection{First hundred numbers}

I have already told you something about Number 1. Page 0 presented as a printing insert the components of the Technical and Administrative Council, the Institute Board of Directors and the description of activities to be developed in the Center-Figure 3-. It is surprising that of the nine Advisers, only three were in the cement business (Marcelo LUMBLER, Patricio PALOMAR and Julián REZOLA, no one as President), despite that financial support for the new Institute came almost exclusively from the INSTITUTO DEL CEMENTO through taxes on all the cement manufactured in Spain and sold in the national market.

An anecdote, today: Number 1 recalls an article from Russian authors KONOVALEV and SKUE -no initials- "HOWTOACCELERATE CLINKERIZATION ADDING FLUORSPAR TO THE CEMENT RAWMIX" that had been published before in the soviet magazine TSEMENT and reported in CHEMICAL ABSTRACTS. No doubt this title can sound familiar to some researchers of the ICCET who, later on -the mentioned work was written in 1949- have worked on the same subject with pretended modernity but surely with success.

A curious fact: Number 1 contains 48 pages format $28 \times 22 \mathrm{~cm}$, and reports did not include graphs nor figures but just blank spaces reserved for them, e.g. see page 23 among others (Figure 4).

The coming numbers followed the same pattern, although from Number 2 an index was included with just the titles of the works (no author), and their corresponding pages. There were figures at the end of each issue, in bright thick paper, very "peculiar" kind of numbering successively even though they 


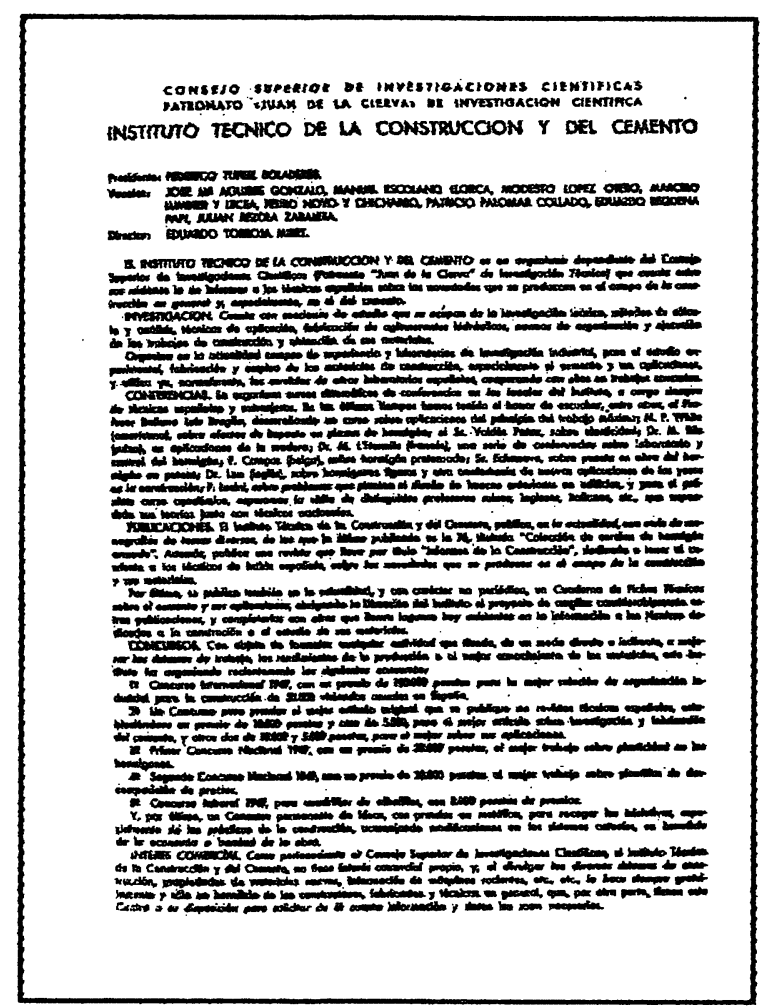

Figura 3.

Figure 3.

diferentes -el redactor ya lo tenía en cuenta al hacer referencia a ellas en los textos de los respectivos trabajos de cada número-.

También en los siguientes a partir del segundo se empezaron a incluir resúmenes de trabajos relativos a HORMIGÓN y otros materiales, de manera que en los índices del Número 3 y correlativos se ordenaban por materias incluyéndolos en cuatro grupos: CEMENTOS; CALES, YESOS Y VARIOS; HORMIGÓN; MÁQUINASY APARATOS.

A partir del Número 18 la presentación de la Revista siguió siendo la misma, aunque con un formato algo más reducido: $24,5 \times 19,5 \mathrm{~cm}$ en lugar de $28 \times 22 \mathrm{~cm}$, como eran los anteriores. En dicho número se insertaba el resumen de un trabajo publicado en forma de fascículo extraordinario del ejemplar de octubre de 1950 de la REVUE DES MATÉRIAUXDE

CONSTRUCTION, dedicado a conmemorar el nacimiento de Henry LECHATELIER.

El número 21 tiene para mí el incalculable valor del recuerdo, el retrotraerme a la fecha de junio de 1951, en la cual lo publiqué con carácter monográfico, con motivo de dar cuenta del primer "CURSO PARA LA FORMACIÓNDEAUXILIARESDELABORATORIO YCONTROLENLA INDUSTRIA DEL CEMENTO" celebrado entre los meses de febrero y mayo de dicho año, cuya preparación y dirección, así como la

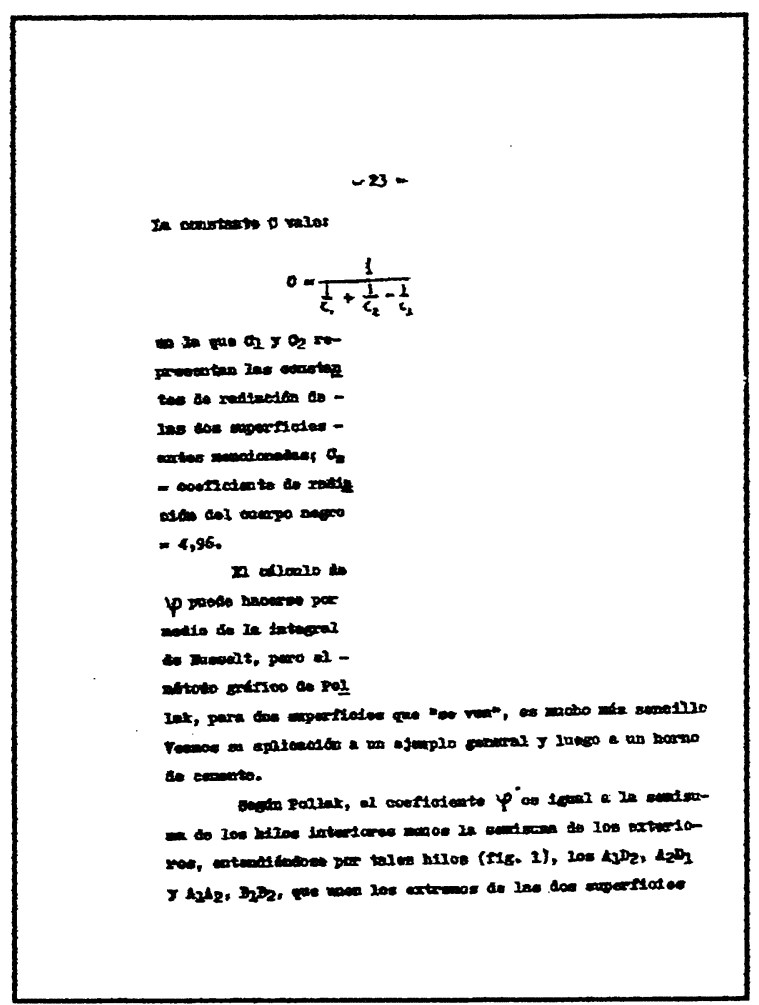

Figura 4.

Figure 4.

belonged to different works. The author who knew this fact, took good care when assigning numbers.

Also Number 2 started including abstracts related to CONCRETE and other materials, thus, from Number 3 Indexes were organized in four groups: CEMENT; LIME-GYPSUMAND SIMILAR; CONCRETE; and MACHINERYANDEQUIPMENT.

The external aspect of the Journal kept being the same for a while, but from Number 18 and on the format was reduced to $24,5 \times 19,5 \mathrm{~cm}$. That number inserted a booklet with an abstract containing $a$ remembrance of Henry LE CHATELIER, that had been published before as an extra issue by REVUE DESMATÉRIAUXDECONSTRUCTION, october 1950.

Number 21 brings to me countless good memories, for in june 1951 I published the report of the first "CURSO PARA LA FORMACIÓNDE AUXILIARES DE LABORATORIO YCONTROL ENLAINDUSTRIA DEL CEMENTO"-COURSE FOR THE FORMATION OF LABORATORY AND CONTROL ASSISTANTSIN CEMENT INDUSTRY- that lasted from february to may same year, where I held the position of Manager 
realización de la parte analítica química del mismo corrieron íntegramente a mi cargo. Fue el primer número en el que aparecía -y además en exclusiva- una firma española. Constaba de 70 páginas y 21 fotografias del Curso, de las cuales la de la Figura 5 muestra el alumnado del mismo acompañado de su Director, en bata blanca. and Scientific Director. It was the first work published in the Journal signed in exclusive by a Spanish author. The work was a monograph, 70 pages, 21 photographs of the course, among them the one in Figure 5 shows the participants with the Director in white cloak.

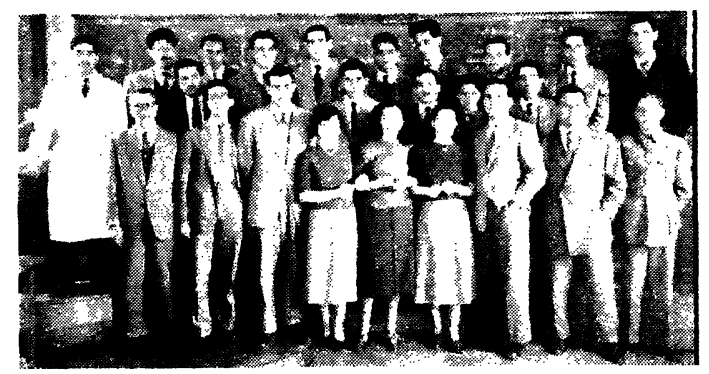

Figura 5.

Figure 5

Las clases teóricas del Curso se dieron en la planta sexta y las prácticas en el laboratorio del bajo y sótano de la entonces sede del ITCC, calle de Velázquez, 47 de Madrid, antes de estrenarse las nuevas y definitivas -actuales- instalaciones del Centro en "Costillares" (Chamartín) el día 6 de junio de 1953. El desarrollo del Curso se anunciaba ya en nota de página antepuesta al índice del Número 14 de la Revista, donde se decía: "en los primeros meses del año próximo " Por año próximo se podía entender 1951, gracias a que al pie de la nota anunciante -por fin, aunque por casualidad-, figuraba ya una fecha: la del 19 de octubre de 1950.

El número 23 tuvo la particularidad de incluir como Anejo, con el mismo formato y número pero en fascículo aparte, el texto íntegro del "legendario" "PLIEGOGENERALDECONDICIONES PARA LA RECEPCIÓNDEAGLOMERANTESHIDRÁULICOS EN OBRAS DECARÁCTER OFICIAL", tema que ya entonces empezaba a despertar interés en el ámbito cementero por la necesidad de la actualización de dicho Pliego. Por el título se puede colegir que no se tenía muy clara la diferencia entre los términos "aglomerar" y "conglomerar", es decir, entre la distinción de matiz significativo que las preposiciones latinas "ad" y "cum" aportan a los verbos y sustantivos a los que se anteponen como prefijos. Me confieso autor del cambio de "aglomerante" por "conglomerante", aunque trabajo me costó y no poco tiempo.

En el número 24 se rompió la monotonía de incluir en la Revista sólo resúmenes de trabajos ya publicados en otras extranjeras. Me cupo el honor de tal ruptura insertando un trabajo de investigación titulado "CONTRIBUCIÓN AL ESTUDIODELA ESTRUCTURADEL CLÍNKERDECEMENTO
Theoretical classes were held in the sixth floor, and practical ones in the basement of the building (Velázquez 47, Madrid), home of the ICCET Headoffice before the permanent one in "Costillares" since 1953. The course had been announced in Number 14, on first page: "early next year ". Next year probably meant 1951, for at last, apparently by chance, a date, october 19, 1950 appeared in it.

Number 23 had the peculiarity of incorporating an Annex, a separate booklet containing the whole "mythical" "PLIEGO GENERAL DE CONDICIONES PARA LARECEPCIONDEAGLOMERANTES HIDRÁULICOSENOBRASDE CARÁCTER OFICIAL" -GENERAL SPECIFICATIONSFOR ACCEPTANCE OF CEMENTS IN PUBLIC WORKS-, which awoke great interest probably because of the need to update it. Through the title it is obvious they did not perceive the nuance between terms "aglomerar" -agglomerate- and "conglomerar" -conglomerate-, that is, between the meaning of Latin prepositions "ad" and "cum" which change the meaning of nouns and verbs carrying them as prefix. I confess myself being the author of the change from "aglomerante" into "conglomerante", although with much effort and no lesser time.

In Number 24 the routine of only including abstracts of works previously published in foreign magazines was broken. I was honored to do so by publishing a research work "CONTRIBUCIÓN AL ESTUDIO DE LAESTRUCTURADEL CLÍNKERDE CEMENTIO PORTLAND. HETEROGENEIDADDELA 
PORTLAND. I.HETEROGENEIDADENLA DISTRIBUCIÓN DE LA CAL LIBRE" (trabajo que, por cierto, se publicó también en alemán en la Revista ZEMENT-KALK-GIPS). Sobre el tema de la Estructura del Clínker volví a insistir en los Números 55 y 58 al 64 , ambos inclusive, y aún después en otros posteriores, como se verá.

A partir del 24 siguieron apareciendo trabajos de autores españoles y así, en el 25, se incluyó otro con el título de "NUEVAS TÉCNICAS PARA EL ESTUDIO DELFRAGUADODELOS “AGLOMERANTES" HIDRÁULICOS -aún no había llegado el cambio de "aglomerante" a "conglomerante"-, el cual continuó en partes sucesivas en los números $26,27,32$ y 41 , así como en la Revista Norteamericana JOURNAL OF THEAMERICANCONCRETEINSTITUTE(JACI) 1952-1953, por cierto que a instancias del Dr. Robert Herman BOGUE que había visitado el ITCC en fecha anterior ofreciéndonos un Seminario sobre "Química del Cemento", título asimismo de su célebre y conocido libro, uno de los "misales" sobre el tema, junto con el que muy pronto voy a citar, del Prof. Dr. Hans KÜHL, alemán, y de algunos otros.

En los mencionados números 26 y 27 , así como en el 28, figuraba también otro trabajo de mi colega, compañero e inolvidable amigo Francisco SORIA, titulado "LAFLOTACIÓNYLAINDUSTRIADEL CEMENTO". Trabajos míos sobre "FRAGUADO", y de SORIA sobre "REFRACTARIOS" volvieron a aparecer en el Número 31.

Siempre que la naturaleza del tema, bien por su extensión o interés así lo requería se tiraba un NÚMERO DOBLE. El primero de ellos fue el 29-30 (de 91 páginas, prácticamente el doble de los ordinarios), con motivo, en este caso, de la publicación de las Normas Francesas para Cemento, como complemento del Pliego Español aparecido en el Anejo del Número 23, como queda dicho, y de la Norma Británica publicada en el 24. En nota de la Redacción se anunciaba también que en números sucesivos se incluirían las Normas Norteamericanas ASTM y otras europeas para información de fabricantes y usuarios españoles de cemento. Comenzaba ya entonces a preocupar -antes sólo a interesar- el tema de las Normas de Cemento y la actualización de las españolas.

Números dobles posteriores hubo varios, particularmente los dedicados a los "COLOQUIOS DE DIRECTORES Y TÉCNICOSDEFÁBRICASDE CEMENTO" (el 118-119, abril/septiembre de 1965, relativo a los Cuartos de 1964, sobre "ORIENTACIONES ACTUALESENLASPLANTAS DE CEMENTO", de los cuales hice el correspondiente
DISTRIBUTIÓNDE LA CALLIBRE"-COONTRIBUTION TOTHE STUDYOF PORTLAND CEMENT KLINKER STRUCTURE: HETEROGENEOUSDISTRIBUTIONOF

FREE LIME- (by the way, this work was also published in German magazine ZEMENT-KALK-GIPS). On this subject-Structure of Clinker-I insisted again in numbers 55, 58 and 64 and further on.

Number 24 maintained the practice of publishing works of spanish authors, so, by Number 25, the title "NUEVAS TÉCNICASPARA EL ESTUDIO DEL FRAGUADODELOS "AGLOMERANTES" HIDRÁULICOS" was included in part, with successive publication in Numbers 26, 27, 32 and 41, and it was also published in JOURNAL OF THE AMERICANCONCRETE INSTITUTE (JACI), 1952-1953, attending the proposal of Dr. Robert Herman BOGUE, who had visited ITCC in 1951, and had prepared for us a Seminar on "Cement Chemistry". His book of the same title is a "cornerstone" on the matter.

Numbers 26, 27 and 28 included a work of my colleague and dearest friend Francisco SORIA: "LA FLOTACIÓN Y LA INDUSTRIA DEL CEMENTO"-FLOTATIONAND CEMENT INDUSTRY-. Works of mine on "SETTING" and of SORIA on "REFRACTORY MATERIALS" appeared again in Number 31.

Every time circumstances did required it length and interest of the work), a double Number was issued. In this particular occasion, number 29-30 (almost twice the usual thick), published the French Standards on Cement, complementary of the Pliego Español appeared in Number 23 Annex, and of British Standards published in 24. An Editors notice announced further publication of American Standards ASTM and other European standards for information of Spanish manufacturers and users. Indeed, the subject had begun to create not only interest, but concern.

Later, there were several double issues specifically those devoted to "COLOQUIOS DE DIRECTORES Y TÉCNICOSDE FÁBRICASDE CEMENTO"-MEETINGS OF DIRECTORSAND TECHNICAL STAFFOFCEMENT FACTORIES-. So, Number 118-119 (april-september 1965), corresponding to 1964 Fourth Meeting about “ORIENTACIONESACTUALESENLAS PLANTASDE 
Resumen y Comentarios, como Coordinador y Ponente General de los mismos; el 138-139 (abril-septiembre 1970) referente a los Quintos de 1969, en el que asimismo presenté el Resumen y Comentarios y la primera ponencia sobre "AUTOMATIZACIÓNDE FÁBRICAS DE CEMENTO”; y el 166-167 (abrilseptiembre 1977), correspondiente a los Sextos de 1976, acerca de "TENDENCIAS EN LA TECNOLOGÍA DELCEMENTOY POSIBLES INNOVACIONES", en los que, como Vicedirector del IETCC presenté, en la Sesión Técnica dedicada a Investigación, Proyección Internacional y Normalización, una Ponencia sobre "PANORAMA FUTURODELA INVESTIGACIÓNENELCAMPO DEL CEMENTO".

Número doble fue también el 150-151 (abrilseptiembre 1973), relativo a las Primeras Jornadas sobre Durabilidad del Hormigón, en las cuales presenté la "Justificación" de las mismas, dos comunicaciones sobre "CORROSIÓN DE ARMADURAS", formando parte de las Presidencias de las Sesiones de Apertura y Clausura y de las relativas a las cinco dedicadas a los respectivos temas científicotécnicos desarrollados en las Jornadas.

En el Número 31, aparte de lo ya dicho antes y por primera vez, apareció el resumen de un trabajo del ya mencionado Prof. Dr. Hans KÜHL publicado en la revista alemana ZEMENT-KALK-GIPS, No.9, septiembre 1951, titulado "CINCUENTA AÑOS DE QUÍMICA DEL CEMENTOEN TEORÍA Y

PRÁCTICA". El Prof. KÜHL es el autor de la, para mí, mejor obra escrita en la época ( $\mathrm{y}$ aún antes y después) -tercera edición actualizada entre 1956 y 1958: tres volúmenes con unas 1.800 páginas-, sobre Química del Cemento ("ZEMENT CHEMIE"), y que traduje del alemán en más de su mitad con intención de publicarla en España. Deseo e intento en el que el Prof. KÜHL me ayudó todo lo que pudo, que no fue poco, pero que no tuvo realidad por causas que se explican en otro lugar (2). El trabajo del Prof. KÜHL concluyó en el Número 32 de ÚLTIMOS AVANCES, primero en el que $j$ al fin! -salvo lo señalado a propósito de los Números 14 y 21 - aparece una fecha: la de junio-julio de 1952, lo cual parecía indicar una periodicidad bimensual. Sin embargo, ésta se mantuvo sólo en el siguiente número 33 , monográfico como el $21, \mathrm{y}$ dedicado al yeso, con un artículo de José María TOBIO, de 36 páginas, 7 figuras y 82 referencias bibliográficas. TOBIO publicaba en el número siguiente, el 34 de octubre de 1952, un resumen de otro trabajo suyo sobre "MODIFICACIONES DIELÉCTRICAS DELAS PASTAS DE CEMENTO DURANTE EL PROCESO DEFRAGUADO", en la misma línea de investigación que los míos basados en la medida de la variación de la conductividad
CEMENTO"-PRESENTTRENDSINCEMENTPLANTSwhich I abstracted and commented as Coordinator and General Reporter; 138-139 (april-september 1970) referring to Fifth Meeting of 1969, which I also abstracted and commented, and presented the first report on "AUTOMATIZACIÓNDE FÁBRICAS DE CEMENTO" -AUTOMATION OF CEMENT PLANTS-; and 166-167 (april-september) corresponding to the sixth Meeting of 1976 on "TENDENCIAS EN LA TECNOLOGIA DEL CEMENTO Y POSIBLESINNOVACIONES-TRENDSIN CEMENTTECHNOLOGYANDPOSSIBLEINNOVATIONSwere I presented, as Vice-director of IETCC, a report on "PANORAMA FUTURODE LA INVESTIGACIÓNENEL CAMPO DEL CEMENTO"-FUTURE PANORAMA OF CEMENTRESEARCH-.

Also a double issue was 150-151 (april-september 1973) dealing with first seminar on Concrete Durability where I presented two reports on "CORROSIÓN DE ARMADURAS"-REINFORCEMENTCORROSION-acting as President at the Opening and Closing sessions, and at the five sessions devoted to Scientific and Technical subjects developed during the seminar.

Number 31, published for the first time an abstract of a work "FIFTY YEARS OF THEORETICAL AND PRACTICAL CEMENT CHEMISTRY of the already mentioned Prof. Dr. Hans KÜHL that had been first published in the German periodical ZEMENT-KALKGIPS, number 9, sept. 1951. Prof. KÜHL is, in my perception, the author of the best work ever written -third edition revised between 1956 and 1958: 3 volumes summing about 1.800 pages- on Cement Chemistry ("ZEMENT CHEMIE"), which I was about to translate with the help of Prof. KÜHL, but could not fulfill the project to the full extent (2). Prof. KÜHL's work concluded in Number 32 of ÚLTIMOS AVANCES dated june-july 1952, which seemingly indicated every other month periodicity, but this interval only lasted until Number 33, which was a monograph devoted to Gypsum with a work by José Maria TOBIO, 36 pages, 7 figures and 82 bibliographical references. TOBIO published in the following issue, Number 34, october 1952 a paper of his work "MODIFICACIONES DIELÉCTRICASDE LASPASTAS DE CEMENTO DURANTE EL PROCESO DEFRAGUADO"-DIELECTRICCHANGESIN CEMENT PASTES DURING SETTING-, in the same research line as mine, based in the measurement of 
-resistividad- eléctrica de las pastas como consecuencia de los procesos de fraguado y endurecimiento.

En el número 37 tuve ocasión de escribir sobre el Tercer Congreso Internacional de Química del Cemento celebrado en Londres, septiembre de 1952, primero de ellos al que asistí. Y en los Números 38 al 43, ambos inclusive, se publicó, íntegramente traducido al español gracias a los buenos conocimientos del alemán que tenía Luis SASTRE CID, por entonces al cargo del contenido de la Revista, un extenso artículo del inolvidable Dr. Ing. Wilhehm ANSELM sobre "EL HORNO VERTICAL", del cual-de ANSELM- guardo un gratísimo recuerdo personal. Este trabajo tuvo continuación en los Números 47 al 51, ambos inclusive. En el 41 se publicaron también las Normas ASTM, y las Federales USA en el 49. En el Número 50 -abril de 1954- se anunciaba la organización de los "PRIMEROS COLOQUIOS DE DIRECTORES Y TÉCNICOS DEFÁBRICASDE CEMENTO", por parte del ITCC, y en el 54 se señalaba la programación de los mismos para los días 25,26 y 27 de octubre de 1954.

A partir del Número 47, al final de cada uno de ellos se añadía una nueva Sección titulada BIBLIOGRAFÍA, indicándose la necesidad de incluir en ella las referencias de los muchos trabajos juzgados interesantes sobre CEMENTO y HORMIGÓN contenidos en las cada vez más numerosas revistas extranjeras que se iban recibiendo en el ITCC, ante la imposibilidad de resumirlos todos con una cierta extensión y detalle. Esta iniciativa partió de Luis SASTRE, y fue mantenida después por Serafin FRAGA.

También fue importante para mí el Número 55, pues, por una parte, anunciaba un " $2{ }^{\circ} \mathrm{CURSO}$ PARA LA FORMACIÓNDE AUXILIARESDE LABORATORIOENLAINDUSTRIADEL CEMENTO", cuya organización, dirección y realización correrían, como las del $1^{\circ}$, a mi cargo; y, por otra parte, reinicié la publicación de una nueva serie de trabajos sobre "CONTRIBUCIÓN AL ESTUDIODELAESTRUCTURA DEL CLÍNKER DECEMENTO PORTLAND", continuación del ya publicado en el Número 24, la cual se extendió a los Números 58 al 64, ambos inclusive, como ya queda dicho, y aún hasta el 79 y el 96 . En los 60 al 66 se incluían métodos de ensayo de las Normas ASTM. El Número 57, Extraordinario de fin de 1954, fue el tercer monográfico que se publicó -lo habían sido antes el 21 y el 33-, con el título de "CONTRIBUCIÓNALESTUDIODELAS NORMASDEDIFERENTES PAÍSES PARAEL CEMENTO PORTLAND", redactadas por el Dr. Demetrio GASPAR TEBAR y el Lcdo. Serafin FRAGA SÁNCHEZ, quien por aquellas fechas electric conductivity variation -strength- of pastes throughout the setting and hardening process.

Number 37 included my report of the Third International Congress on Cement Chemistry, held in London, september 1952. It was the first congress I had ever attended. Numbers 38 to 43 contained the whole extensive work, "EL HORNO VERTICAL" -THE SHAFT KILN-translated by Luis SASTRE CID, written by the unforgettable Dr. Ing. Wilhelm ANSELM, whose memory I cherish. This publication was extended to Numbers 47 to 51 . Number 41 published ASTM standards, and Number 49 USA Federal Standards. In Number 50 -april 1954-, the ITCC announced a series of seminars on "PRIMEROS-FIRST-COLOQUIOSDEDIRECTORES $Y$ TÉCNICOS DE FÁBRICAS DE CEMENTO", to be held in october 25, 26 and 27, 1954, but the program did not appeared until Number 54.

From Number 47 on, a new section was added to the Journal. It was called BIBLIOGRAFÍA -BIBLIOGRAPHY- and included references of the many works acknowledged for their interest on CEMENT and CONCRETE, drawn from prestigious foreign publications. This was Luis SASTRE's initiative, and Serafin FRAGA was later in charge of the Section.

Number 55 was most relevant for me since it announced the " ${ }^{\circ}$ CURSO PARA LA FORMACIÓNDE AUXILIARESDELABORATORIO ENLA INDUSTRIA DEL CEMENTO", which organization, direction and development were under my responsibility (same as in the First one). Also in that number I restarted publishing a new series on "CONTRIBUCIÓN AL ESTUDIO DE LA ESTRUCTURA DEL CLINKER DE CEMENTO" a follow up of a work already published back into Number 24, and that was further extended to Numbers 58 to 64. Numbers 60 and 66 included ASTM Standards for test methods. Number 57, an extra issue at the end of 1954, was the third monograph published (Numbers 21 and 33 had been before) which title "CONTRIBUCIÓN AL ESTUDIO DE LASNORMASDE DIFERENTES PAÍSESPARA EL CEMENTO PORTLAND"CONTRIBUTIONTOTHE STUDYOF PORTLAND CEMENTINDIFFERENTCOUNTRIES-was written by Dr. Demetrio GASPAR TEBAR and BA. Serafin FRAGA SÁNCHEZ. At that time, FRAGA 
sustituyó a Luis SASTRE en la confección de la Revista. A su vez, a FRAGA le sustituyó andando el tiempo y con carácter casi "vitalicio", el Aparejador Carlos SÁNCHEZCASTRO, hoy yajubiladoy afortunadamente gozando de buena salud.

En el número 73 (junio-julio 1956) publiqué mi primer trabajo sobre Aditivos para Hormigón, el cual había sido presentado al XXVIII Congreso Internacional de Química Industrial y llevaba por título "INFLUENCIA DELA ADICIÓNDEDETERMINADOS AGENTES TENSOACTIVOSENLARETRACCIÓNDEPASTAS YMORTEROS DECEMENTO PORTLAND". El trabajo se centraba en la parte fisicoquímica teórica de los mecanismos de acción de los productos tensoactivos dispersantes, colectores, floculantes, humectantes, espumantes utilizados en flotación de minerales y recientemente entonces como aditivos para hormigón. Se prolongó en los Números 74 y 75. En el 73 aparecía también un artículo editorial de Serafin FRAGA sobre "ACCIONES AGRESIVAS SOBRE EL HORMIGÓN".

En los Números 76, 77 y 78 se publicó íntegro un trabajo titulado "AUMENTO DE LA PRODUCCIÓN DECEMENTOY MEJORA SIMULTÁNEA DELA CALIDAD", el cual fue galardonado con el Premio "JUAN DE LA CIERVA" de Investigación Técnica del CSIC, para trabajos de autor, en 1956.

En el 79, de febrero de 1957, se anunciaba la celebración en marzo de dicho año de los "Il COLOQUIOS DEDIRECTORES Y TÉCNICOS DE FÁBRICAS DE CEMENTO"-los I tuvieron lugar, como queda dicho, en octubre de 1954-. En él se incluía también el comienzo del trabajo titulado "SOBRE LA ESTRUCTURA DEL CLÍNKER DE CEMENTO PORTLAND", presentado a la "III REUNIÓN INTERNACIONAL SOBRE REACTIVIDAD DE LOS SÓLIDOS”, celebrada por entonces en Madrid, y que constituía continuación de los del mismo tema ya publicados en los Números 24 y 58 al 64, como queda dicho. Curiosamente la continuación de este trabajo no tuvo lugar en el Número 80, sino que en éste se publicó integramente, repitiéndose la parte ya aparecida en el 79.

La razón para ello no pudo ser más satisfactoria: El Número 80 (marzo-abril 1957) de la Revista "ÚLTIMOS AVANCES en Materiales de Construcción", a partir del cual se llamaría "MATERIALES DECONSTRUCCIÓN. Últimos avances", ya como subtítulo, ¡fue el primero en aparecer impreso!, abandonándose la tirada en multicopista que tantos años había durado. La revista cambió también de presentación incluso en la portada substituted SASTRE in the making of the Journal, who was substituted in turn by Carlos SÁNCHEZ CASTRO, who stayed in charge until he retired, which he did in very good health.

In Number 73 (june-july 1956) I published my first work or Admixtures for Concrete: "INFLUENCIA DE LA ADICIÓN DETERMINADOSAGENTESTENSOACTIVOSENLA RETRACCIÓNDE PASTAS YMORTEROS DE CEMENTO PORTLAND"-THE INFLUENCE OF ADDING SOME TENSOACTIVE AGENTS INTHE SHRINKAGEOF PORTLAND CEMENT PASTES AND MORTARS- that had been presented first to the 28th International Congress on Industrial Chemistry:. The work focused on the theoretica. physical and chemical aspect of mechanisms of tenso-acti dispersants, collectors, humectants, foaming products, etc. used in flotation of minerals, and recently

-at that time- as admixtures for cements and concretes (it extended to Numbers 74 and 75). In Number 73, you could find FRAGA's editorial on "ACCIONES AGRESIVAS SOBF EL HORMIGÓN"-AGGRESSIVE ACTIONSONCONCRET

In Numbers 76, 77 and 78, an important work: "AUMENT, LA PRODUCCIÓNDE CEMENTO YMEJORA SIMULTÁNE LACALIDAD"-CEMENTPRODUCTIONINCREASEAND SIMULTANEOUSIMPROVEMENTOFCEMENTQUALITYpublished and awarded with the Technical Research Prize "JUAN DE LA CIERVA" -CSIC-, in 1956.

Number 79, february 1957, announced the celebration, next march, of the "II COLOQUIO DE DIRECTORES Y TÉCNICOS DE FÁBRICAS DE CEMENTO" This number also included first part of the work "LA ESTRUCTURA DEL CLINKER DE CEMENTO PORTLAND" which had been presented in the III REUNIÓN INTERNACIONAL SOBRE REACTIVIDAD DE LOS SÓLIDOS" $3^{\text {rd }}$ INTERNATIONALMEETING ONSOLIDSTATE REACTIVITY-, held in Madrid as a follow up of previous ones on the same subject, already published in numbers 24 and 25 to 64 . Surprisingly, Number 80 published the entire work repeating what had been published in Number 79.

The reason was a good one. Number 80 (april-march 1957) of "ÚLTIMOS AVANCES en Materiales de Construccion" that was to be called onward "MATERIALESDE CONSTRUCCIÓN-Últimos avances" (now as subtitle), was the first to be printed after so many years using the duplicator machine. The journal changed not only the design of the cover but 
y de formato, pasando de $28 \times 22 \mathrm{~cm}$ a $25 \times 20 \mathrm{~cm}$ (Figura 6: compárese con la Figura 1), y la Sección de BIBLIOGRAFÍA que siguió apareciendo al final, iba como encarte en hojas de otro color -verde- y más estrechas. Naturalmente, no se podía estrenar el primer ejemplar impreso incluyendo un trabajo "partido".

El número 80 contenía también el resumen amplio de las intervenciones en el acto inaugural de los citados II Coloquios, redactado por quien esto escribe. En sucesivos números, hasta el 84 inclusive, se publicaron integras las comunicaciones aportadas a los mismos.

En el 81 este autor inició una nueva serie de publicaciones sobre "MÉTODOS DE ANÁLISIS QUÍMICO DEL ITCC APLICADOS AL CEMENTO PORTLAND", la cual, con la colaboración de los Ingenieros Técnicos José Manuel FERNÁNDEZ PARÍS y Bernardo BACLE GONZÁLEZ se extendió a los Números 91, 99, 100, 107 y otros posteriores. Esta serie de trabajos daría lugar a la concesión del Premio de Investigación Científica y Técnica del Patronato "Juan de la Cierva" del CSIC para equipos investigadores.

En el Número 82, dedicado a los "II COLOQUIOS DE DIRECTORES Y TÉCNICOS DEFÁBRICASDE CEMENTO", no puedo dejar de mencionar la aportación de mi admirado y buen amigo el Ing. Antonio SARABIA GONZÁLEZ, Director Técnico que fue de la fábrica de CEMENTOS HISPANIA, en Yeles (Toledo), sobre una regla de cálculo para el de la composición de crudos y potencial del clínker de cemento, la cual se materializó en plástico, gracias a gestiones realizadas por mí con el entonces Coronel Director del Taller de Precisión de Artillería en Madrid, dada la necesidad de gran exactitud en las divisiones de la regla y de la reglilla del "artilugio"-SARABIA lo llamaba "dispositivo"-; exactitud o, por mejor decir, "precisión" que se lograba con las máquinas de que disponía el citado taller.

En el Número 85, vueltos ya a la "normalidad", se publicaron varios artículos de miembros del ITCC, entre ellos el titulado: "TRATAMIENTOS TÉRMICOS DEL HORMIGÓN", de este autor y el de P. GARCÍA DE PAREDES sobre "CENIZAS VOLANTES", que tendría su continuación en otro del Número 96.

En el 86, y de nuevo en relación con los aditivos para hormigón se publicó otro trabajo de este autor con el título "EL CLORURO CÁLCICOCOMO ACELERADORENLA PREFABRICACIÓNDEL HORMIGÓN"; y otro del Dr. TOBIO sobre un "ESCLERÓMETROROTATIVOAUTOMÁTICO". Tengo que decir ya que TOBIO era tan Físico o más que Químico, y muy bueno en ambos aspectos. Y aún un tercero de "Don Pablo" GARCÍA DE PAREDES sobre "LAMAGNESIA ENLOS AGLOMERANTES also the format which got smaller, going from $28 \times 22 \mathrm{~cm}$ to $25 \times 20 \mathrm{~cm}$ (compare Figure 6 with Figure 1), and BIBLIOGRAFIA section was an insert of a different color green and narrower. Obviously, it would have been awful to issue first printed number with the second part of a "split" work.

Number 80 also contained a broad abstract of the participations in the opening sessions of the 'II Coloquios' written by myself. In following numbers until 84 , these participations were published unabridged.

In Number 81 I initiate a new series of publications on "MÉTODOS DE ANÁLISISQUÍMICODELITCC APLICADOSAL CEMENTOPORTLAND"-CHEMICAL ANALYTICMETHODSOFITCCAPPLIEDTO PORTLAND CEMENT-, in collaboration with Technical Engineers José Manuel FERNÁNDEZ PARIS and Bernard BACLE GONZALEZ, which had extensions in Numbers 91, 99, 100, 107 and other subsequent numbers. This series won the Patronato "Juan de la Cierva" (CSIC) prize for Scientific and Technical Research, a grantee for research teams.

From Number 82, entirely devoted to "II COLOQUIOS DE DIRECTORES Y TÉCNICOSDE FÁBRICASDE CEMENTO", I can recall the contribution of my good and admired friend Ing. Antonio SARABIA GONZALEZ, -former Technical Director of the CEMENTOS HISPANIA factory, at Yeles (Toledo)-, consisting on a calculus ruler intended to reckon the composition of raw materials and the potential of Portland cement clinker. Made of plastic, it had been possible to carry it out thanks to steps taken by myself with former Colonel Director of the Taller de Precisión de Artilleria-Artillery Precision Workshop- in Madrid, for the great "precision" required in the divisions and subdivisions of the "gadget"-SARABIA called it "device"- was reached with mechanisms available in that specific work place.

In Number 85, back to "normality", several articles from ITCC members were published, among them "TRATAMIENTOS TÉRMICOSDEL HORMIGÓN" -THERMAL TREATMENTS FOR CONCRETE-, -I was the author myself-, and "CENIZAS VOLANTES" -FLY ASHES- by P. GARCÍA DE PAREDES which was to be continued in another work published in Number 96. In Number 86, and again referring to admixtures for concrete, two works were published, one of mine " $E L$ CLORUROCALCICO COMOACELERADORENLA PREFABRICACIÓNDEL HOMIGÓN"-CALCIUM CHLORIDE ASACCELERATORINCONCRETE PREFABRICATION-; and another of Dr. TOBIO about a "SCLERÓMETROROTATIVOAUTOMÁTICO" -AUTOMATIC ROTARY SCLEROMETER-. It is time now to tell you that TOBIO liked Physics as much, or more, as 


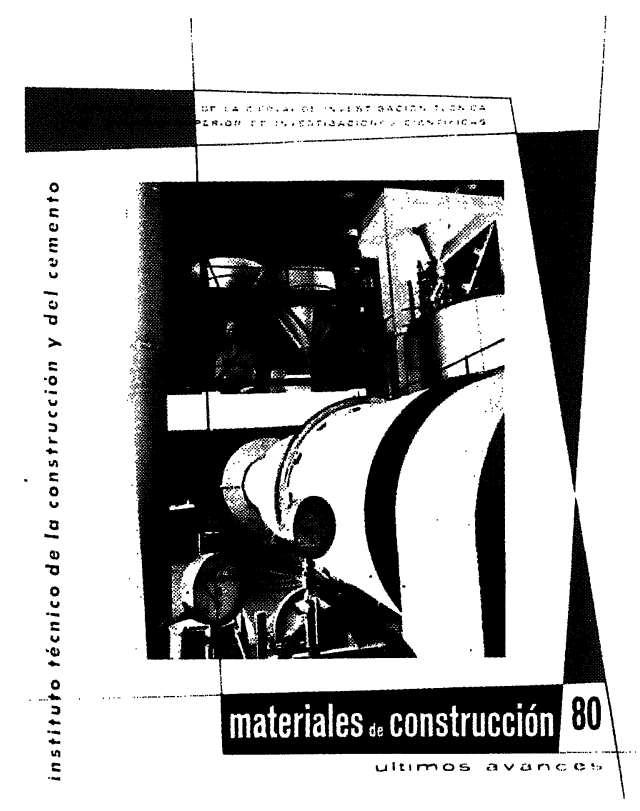

Figura 6.

Figure 6.

HIDRÁULICOS CON ESCORIAS". Y en el Número 87 apareció un trabajo más acerca de "UN CALCÍMETRO GRAVIMÉTRICO", aparato o también "artiluģio" analítico diseñado y aplicado por quien escribe

El Número 88 fue "bueno" y "malo" a la vez. Bueno, porque en él apareció un trabajo interesante del Dr. José María TOBIO acerca del "EMPLEO DEL BLOQUEDE YESOPARA LADETERMINACIÓN DELA HUMEDADENLASPASTASDE

CEMENTO", y con segunda parte en el Número 99; y malo porque, inmediatamente a continuación de éste, figuraba otro sobre "ENSAYOS DE COCINAS ESPAÑOLAS" que, la verdad, no venía a cuento en una revista dedicada a materiales de construcción, pero que incomprensible y tal vez subrepticiamente se metió "de clavo". En el Número 89 otro trabajo de este autor versó sobre "POSIBILIDADES DE CONOCER LA EDAD DE UNA OBRA", tema que por entonces se planteó con interés. El Número 93 contenía otro trabajo de GARCÍA DE PAREDES sobre "CENIZAS DE COMBUSTIBLES ESPAÑOLES.PROPIEDADES AGLOMERANTES", uno de los primeros nacionales sobre cenizas volantes junto con el del Número 85. El tema de las "Cenizas Volantes" fue el objeto de la Tesis Doctoral de José Luis ALONSO RAMÍREZ, que se ocupó de recabar a través de ASINEL muestras de todas las de las centrales térmicas españolas. En el 96 se reanudaba la serie de trabajos de quien escribe, acerca del clínker, con el titulado "LOS ÁLCALIS EN
Chemistry, and he was very good in both fields. A third work from "Don Pablo" -GARCÍA DE PAREDES- about "LA MAGNESIA ENLOS AGLOMERANTES HIDRÁULICC CONESCORIAS"-MAGNESIUMOXYDE IN CEMENTS CONTAINING BLAST FURNACE SLAG-was also publishe in Number 86. Number 87, published one more work abor "CALCÍMETRO GRAVIMÉTRICO"-A GRAVIMETRICLIN METER-, a device -or analytical "gadget"- designed anc operated by myself.

Number 88 was "good" and "bad" at the same time. "Good", because an interesting work by Dr. José Maria TOBIO about "EMPLEO DEL BLOQUE DE YESO PARA I DETERMINACIÓNDE LA HUMEDAD ENLASPASTASDI CEMENTO"-THE USE OF GYPSUM BLOCK FOR THE MEASUREMENTOF HUMIDITY INCEMENT PASTES-, appeared (it had a Part II in Number 99); and "bad", because following this came another on "ENSAYOS DE COCINAS ESPAÑOLAS"-TESTS ON SPANISH STOVES-. which did not fit within a Journal devoted to construction materials, and that probably was inserted surreptitiously with who know what purpose. In Number 89, another wor of mine appeared: "POSIBILIDADES DE CONOCER LA EDAD DE UNA OBRA"

-POSSIBILITY TO KNOW THE AGE OF A WORK-, a subjec that woke interest at that time. Number 93 included anoth work by GARCÍA DE PAREDES on "CENIZAS DE COMBUSTIBLESESPAÑOLES. PROPIEDADES

AGLOMERANTES"'-BINDING PROPERTIESOF SPANISF. COAL ASHES-, one of the first on that subject, at national level, together with the one appeared in Number 85.

"Flying Ashes" was also the subject of José Luis ALONS, RAMÍREZ PhD. thesis. For this purpose he accomplished i task of gathering, through ASINEL-ASSOCIATIONOFELECTRICITYINDUSTRIES (Thermoelectric Plants)-, samples from all Spanish power plants. In 96 a series of works of mine about clinker: " $L C$ 
LA ESTRUCTURA DEL CLÍNKERDECEMENTO PORTLAND", el cual tuvo continuación en el número siguiente.

El Número 97 (enero-febrero-marzo 1960) supuso otro cambio de presentación, pasándose del formato $25 \times 20$ del Número 80 y siguientes, bimensuales, al de $27 \times 21$ casi como al principio: $28 \times 22$, variándose también la portada (Figura 7) y dándose más "colorido" al interior: índice, títulos y figuras. La verdad es que bien podía haberse esperado al número 100 , más "emblemático", para llevar a cabo el cambio, pero primó más la circunstancia de ser el 97 el primer número ya trimestral, del año 1960 , final de lustro y de decenio. $Y$ un paso atrás, que todo hay que decirlo: a partir de este número en el índice de cada uno, que desde el Número 3 incluía las páginas en las que aparecían los trabajos de los títulos correspondientes, afectados de números de clasificación decimal que para poco o nada servían, ¡ise suprimió la indicación de las páginas y la paginación de las hojas de la Revista, manteniéndose solamente el inútil número de la clasificación decimal! Afortunadamente este fallo "sólo" se extendió hasta el Número 102, pues en el 103 volvió a aparecer el paginado.

En el Número 100 (octubre-noviembre-diciembre) con el que acababa el año 1960 se daba cuenta del desarrollo de los "III COLOQUIOS SOBRE DIRECTORES Y TÉCNICOS DEFÁBRICAS DE CEMENTO", celebrados en dicho año. Los trabajos presentados a estos Coloquios se publicaron en los sucesivos números 101, 102 y 103. Así, por ejemplo, en el 101 se publicó la aportación del para mí inolvidable amigo el Prof. Dr. Giovanni MALQUORI,
ÁLCALISENLA ESTRUCTURADEL CLÍNKERDE CEMENTO PORTLAND"-ALKALISIN THE STRUCTURE OF PORTLAND CEMENT CLINKER-was retaken, and continued and ended in the following number.

Number 97 (january-february-march) brought a new change in the aspect of the Journal: format $25 \times 20$ adopted in Number 80 (bimonthly) became $27 \times 21$ almost like at the beginning $(28 \times 22)$, the cover also changed (Figure 7) and the interior -index, titles and figures-was more "colorful". As a matter of fact they could have waited to make that change until Number 100, more "emblematic", but the fact that Number 97 (quarterly from now on) was first number of the year 1960 and end of a decade decided the change. And one step backward indeed, that is to say that from this number, the index, that from Number 3 included the number of the page assigned to each work with its corresponding decimal classification that was of little or of no use at all, numeration was suppressed but the useless classification number was kept! Fortunately this mistake "only" lasted until Number 102; Number 103 was paginated again.

In Number 100 (october-november-december) closing number of year 1960 published the report of "III COLOQUIOS SOBRE DIRECTORES Y TÉCNICOSDE FÁBRICAS DE CEMENTO" held that same year. Works presented at this "Coloquios" were published in following numbers 101,102 and 103. For example: Number 101 published the contribution of my unforgettable friend Prof. Dr. Giovanni MALQUORI, on "ASPECTOS DE LA INDUSTRIA ITALIANA DEL CEMENTODURANTE EL

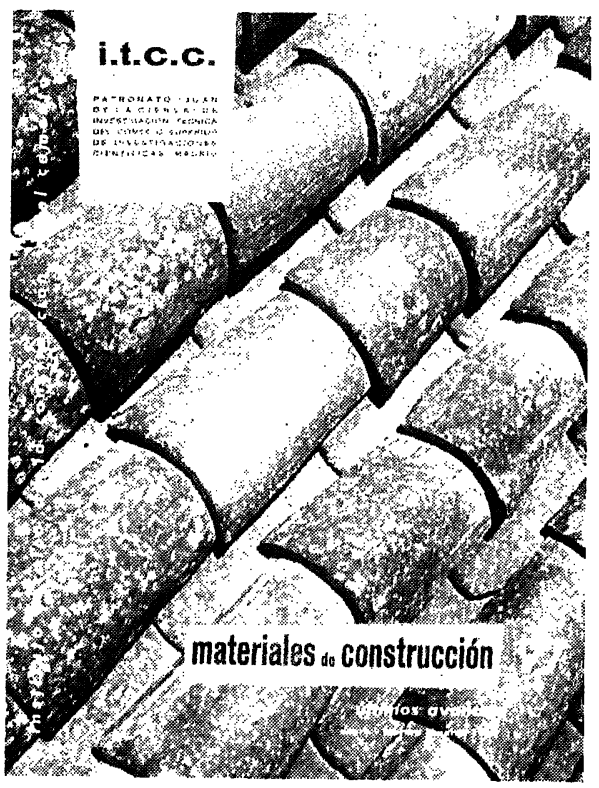

Figura 7.

Figure 7 . 
sobre "ASPECTOS DE LA INDUSTRIAITALIANA

DELCEMENTODURANTEELÚLTIMO

QUINQUENIO (1955-1959)". Y otro mío, extenso, acerca de "LOS CEMENTOS ESPAÑOLES ANTELA PROPUESTA DE UNNUEVO PLIEGO GENERAL DE CONDICIONES". Y en el 102, el de "COMBUSTIÓN Y COMBUSTIBLES", del asimismo recordado Ing. Alberto VIRELLA, colaborador tiempo después, conmigo, en la traducción del alemán del libro de Otto LABAHN "Ratgeber für Zementingenieure" "PRONTUARIO DEL CEMENTO", publicado por EDITORES TÉCNICOSASOCIADOS, S.A.de Barcelona, en 1985.

\section{HISTORIA MODERNA}

Habiéndome hecho el propósito eso sí, de forma unilateral, convencional y arbitraria de considerar como "protohistoria" de la Revista la correspondiente a sus 100 primeros números, aquí debería acabar $\mathrm{mi}$ repaso. No obstante, creo conveniente penetrar un poco en la que sería su "historia moderna" extendida a los seguidos 100 números de la misma, es decir, hasta el 200, aunque de una manera rápida, esquemática y sincopada, dejando para las "nuevas generaciones", ya maduras, el tratamiento de la "historia contemporánea", si algún día tienen a bien ocuparse de ella. Otra razón para hacerlo así es que se me acaba si no es que se me ha acabado ya el espacio concedido para esta exposición eutrapélica. Y a ello voy de nuevo y con el mismo propósito de hacer destacar las aportaciones originales de los químicos del ITCC, como homenaje a los de todos los tiempos, con perdón por la parte que pueda tocarme.

\subsection{Los cien segundos números}

En el Número 109 (enero-febrero-marzo) o en el 110 (abril-mayo-junio) de 1963 se subsanó otro de los "defectos" de la Revista: en el índice se incluyó, además del título del trabajo publicado, el del autor o autores. Ya a partir del Número 121 los títulos en español se repetían en inglés y francés, lo cual supuso otra "mejora" que dejó de serlo en el número 161 en el que se suprimieron.

Números singulares de esta etapa fueron el doble 138139 en el cual apareció por vez primera, para prolongarse en el futuro, un "Comité de Redacción" de la Revista, formado por los Profs. Drs. Francisco ARREDONDO, José CALLEJA, Francisco SORIA y José María TOBIO. Al poco tiempo -Número 152 y siguientes- ARREDONDO fue sustituido en dicho Comité por el Dr. Demetrio GASPAR, entrando también a formar parte del mismo Don Pablo GARCÍA DE PAREDES. En los Números 133 y 135 se trataba
ÚLTIMO QUINQUENIO (1955-1959)"-ASPECTS OF THE ITALIANCEMENTINDUSTRYDURING THE LASTLUSTRU (1955-1959)-; and another by myself, an extensive one ab "LOS CEMENTOS ESPAÑOLESANTE LA PROPUESTA DI UN NUEVO PLIEGO GENERAL DE CONDICIONES" -SPANISH CEMENTSINRELATION WITH THE PROPOSA. OF NEW CEMENT STANDARDS-; and, in Number 102, another on "COMBUSTIÓN Y COMBUSTIBLES", by the r remembered Ing. Alberto VIRELLA, who further on collaborated with me in the translation, from German, of $t$ book "Ratgeber für Zementingenieure"- "PRONTUARIO DEL CEMENTO" (CEMENT HANDBOOK) published by EDITORESTÉCNICOS ASOCIADOS, S.A. -ASSOCIATED TECHNICAL PUBLISHERS-, Barcelona, 1985.

\section{MODERN HISTORY}

Having deliberately taken the decision -of course an unilateral, conventional, and arbitrary one- of considerin. the Journal "protohistoria" the first set of one hundred numbers my revision should finish here. However, I consi. it suitable to just access in what would be its "modern history" -extended to one more set of 100 numbers, which means until number 200-although in a quick, schematic a scattered way, yet leaving for mature "new generations" composition of "contemporary history", if they are willin do so. Another reason for my decision is that the space. assigned to me for this earnest exposition is about to end. And here I am again on the task ready to remind once aga: the original contributions of researchers on cement chemi at the ITCC, as a tribute to researchers of all times, includ my modest share.

\subsection{Second set of hundred numbers}

In Number 109 (january-february-march) or in number 11 (april-may-june) 1963, another of the "shortcomings" of Journal was eliminated: to the title of each work publisher the name of the authors was included in the index. And yei from Number 121 titles in Spanish were translated into English and French, which was an improvement that just lasted until suppressed in Number 161.

Numbers truly unique during this stretch of time were the double issue 138-139 where a "Comité de Redacción", wi Profs. Drs. Francisco ARREDONDO, José CALLEJA, Franc SORIA and José Maria TOBIO, was constituted for the firs. time. Later, from Number 152, ARREDONDO was substitut by Dr. Demetrio GASPAR, and Don Pablo GARCÍA DE PAREDES was appointed to the post. For Numbers 133 an 135 a I wrote a report of the "V SIMPOSIO INTERNACION DEQUÍMICA DEL CEMENTO"-FIFTHINTERNATIONAL CONGRESS ON CEMENT CHEMISTRY-, held in Tokio 196. 
del "V SIMPOSIO INTERNACIONAL DEQUÍMICA DEL CEMENTO" celebrado en Tokio en 1968, por parte de quien esto escribe, asistente al mismo. Y en el 137 aparece por última vez, ipor fin!, la inútil y confusa numeración de la clasificación decimal. El Número 152 fue el último que apareció con el titulo de "MATERIALES DECONSTRUCCIÓN"y el subtítulo de "Últimos Avances". Un segundo cambio de titulación hizo que en adelante, hasta hoy y más, la Revista se llame sólo "MATERIALES DE CONSTRUCCIÓN". El Número 153 supuso otro cambio de formato: el ejemplar de la Revista creció, pasando de 27 × $21 \mathrm{~cm}$ a $29,5 \times 21 \mathrm{~cm}$. En los 155 y 158 se glosaron los actos y el contenido del " 40 ANIVERSARIO $2^{a}$ ASAMBLEA DEL IETCC"-lo de " 2 " es harto discutible- y en los 156 y 175 se daba cuenta de la $1^{\mathrm{a}}$ y $2^{\mathrm{a}}$ Reuniones del "GLAICYC" (Grupo LatinoAmericano de Instituciones del Cemento y del Concreto -por cierto, sigla ideada por quien escribe para "bautizar" a dicho Grupo-), respectivamente celebradas en Medellín (Colombia) 1973 y Río de Janeiro (Brasil) 1979 , con asistencia y actuación de este autor. En el Número 158 éste daba cuenta de sus impresiones acerca de la Investigación en Cemento y de la Industria Cementera de la URSS, con motivo de su asistencia al " $7{ }^{\circ}$ CONGRESO INTERNACIONALDEQUIIMICA DEL CEMENTO", Moscú, 1974, al cual hizo alguna aportación.

Más singulares números de este segundo centenar fueron los dobles 118-119 y 138-139 dedicados a los "IV y V COLOQUIOS DE DIRECTORES Y TÉCNICOS DE FÁBRICAS DE CEMENTO”, de 1964 y 1969, respectivamente; el 150-151 (abril-septiembre) asignado a las "JORNADAS DE DURABILIDADDEL HORMIGÓN", celebradas por dichas fechas; y el 166167 dedicado asimismo a los VI y últimos de dichos COLOQUIOS (los de 1976) de la Primera Etapa de los mismos -la del ITCC- como ya se expuso anteriormente.

En los números 183, 188 y 192 se daba cuenta de las Reuniones del Comité Científico EuroAsiático para el "VIIICONGRESOINTERNACIONALDEQUÍMICA DEL CEMENTO", Río de Janeiro, 1986, en el cual tuve una participación muy activa.

En el Número 183 se incluía además un trabajo experimental llevado a cabo por el Sector Cementero español sobre "INVESTIGACIÓN INDUSTRIALDEL AHORRO ENERGÉTICOENLAFABRICACIÓNDE NUEVOS CEMENTOS ESPAÑOLES", firmado por nueve autores y presentado por quien esto escribe, bajo los auspicios de OFICEMEN, en el "COLLOQUE INTERNATIONALSURLESLAITIERSETLES CIMENTS AUX AJOUTS", Mons (Bélgica) 1981. Y en otro Número doble, el 190-191, de julio a septiembre since I was among the assistants. And in Number 137 the useless and confuse decimal classification numbers at last disappeared!. Number 152 offered for the last time the titled "MATERIALES DE CONSTRUCCIÓN" and "Últimos avances" as subtitle. After this second change and until today the Journal was to be called "MATERIALES DE CONSTRUCCIÓN". Number 153 brought another change in the format: it became larger, from $27 \times 21 \mathrm{~cm}$ to $29,5 \times 21 \mathrm{~cm}$. In Numbers 155 and 158 the development and content of the " $40^{\text {th }}$ ANNIVERSARY, $2^{\text {nd }}$ ASSEMBLY OF THE IETCC" $-2^{\text {nd }}$ would be somehow a matter of discussion-, and in Numbers 156 and 175 the $1^{\text {st }}$ and $2^{\text {nd }}$ "GLAICYC" Meetings (Grupo Latino-Americano de Instituciones del Cemento y del Concreto-Latin-American Group of Institutions of Cement and Concrete-) -by the way it is me who named this group after its initials- respectively held in Medellin (Colombia) 1973 and Rio de Janeiro (Brasil) 1979, with my assistance and participation. In Number 158 I expressed my thoughts about Cement Research and Industry in the URSS, after my participation in the "VII CONGRESO INTERNACIONAL DEQUIMICA DEL CEMENTO"- Th INTERNATIONAL CONGRESS ON CEMENT CHEMISTRY-Moscow, 1974.

Special numbers within this $2^{\text {nd }}$ set of hundred issues were double Numbers 118-119 and 138-139 devoted to "IV y V COLOQUIOSDE DIRECTORES Y TÉCNICOSDE FABBRICAS DE CEMENTO", 1964 and 1969 respectively; Number 150-151 (april-september) was devoted to "JORNADASDE DURABILIDAD DEL HORMIGÓN" -CONCRETE DURABILITY SEMINAR-held at that time; Number 166-167 devoted to the VI and last of COLOQUIOS (those of 1976) of the First period -that of ITCC-mentioned before.

Numbers 183, 188 and 192 reported the Meetings of Euro-Asian Scientific Committee for the "VIII CONGRESO INTERNACIONAL DEQUIMICA DEL CEMENTO", Rio de Janeiro, 1986, where I had a very active participation.

Number 183 also included an experimental work, conducted by the Spanish Cement Sector, on "INVESTIGACIÓNINDUSTRIAL DELAHORRO ENERGÉTICOENLAFABRICACIÓNDENUEVOS CEMENTOSESPANTOLES"-INDUSTRIALRESEARCHON ENERGYSAVING INTHE MANUFACTUREOF NEW SPANISH CEMENTS-, within the COLLOQUE INTERNATIONAL SUR LES LAITIERSETLESCIMENTS AUX AJOUTS", Mons (Belgium) 1981. And by the time of another double issue, 190-191, july through september 
de 1983, dejé de figurar como miembro del Comité de Redacción -me jubilaron en 1984-.

El Número 197 (enero-febrero-marzo 1985) contenía un primer artículo dedicado a la conmemoración del 50 Aniversario del Instituto de la Construcción y del Cemento "Eduardo Torroja" -dicho así sería el "ICCET" y no el "IETCC"-, Pero lo curioso del caso es que este artículo, sin firma de autor en cabecera ni al final del mismo, ni con indicación de que se trataba de un editorial de la Revista, daba cuenta de las sesiones de apertura y clausura de los actos conmemorativos del Cincuentenario, así como de las intervenciones de las personalidades que en ellos tomaron parte. Muchas veces antes, en situaciones idénticas o análogas, el relator de turno figuraba con nombres y apellidos, titulaciones y cargos, como suele ser normal. Y en el Número 199 y a partir del mismo se dio a conocer que se haría cargo de la Revista el Dr. Tomás VÁZQUEZ MORENO, figurando a la cabeza del Comité de Redacción de la misma. En el momento presente lo es, como queda dicho, la Dra. Francisca PUERTAS.

Finalmente, en el Número 200 y siguientes hasta hoy no cambió el formato de la Revista, pero sí la presentación en el Número 201 (enero-febrero-marzo 1986) Figura 8, la cual se conserva actualmente en el Número 262, y en este doble conmemorativo 263-264 (julio-diciembre 2001).

En los números del segundo centenar continuó la aparición asidua de trabajos de los que pudieron considerarse "pioneros" de la Revista: CALLEJA,
1983, I resigned from the "Comité de Redaccion" -I retired in 1984-.

Number 197 (january-february-march) contained a memoir of the $50^{\text {th }}$ Anniversary of the Instituto de la Construcción y del Cemento "Eduardo Torroja" -which is to say that initials would be "ICCET" and not "IETCC"-. The peculiarity of this article, without author's name on top or at the end, and neither indicating that it was an editorial, it reported the inauguration and closing Anniversary sessions, and the interventions of participants as well. Many times in identical or analogous situations, reporter's name had appeared with first name, surname, career degree and position held, as it normally happens. And in Number 199 announcement was made that Dr. Tomás VAZZUEZ MORENO would be the Director in charge of the Journal and Head of the Editing Committee. For the present it is Dr. Francisca PUERTAS who holds this position.

Finally, from Number 200 until today the format of the Journal remains unchanged, but not the presentation. Number 201 (january-february-march 1986), -Figure 8- bc a change in presentation, and this new one has remained what it is today in Number 262 and in this commemorating double issue 263-264 (july-december 2001) it shall be the same.

In this second set of one hundred numbers, "pioneers" of Journal: CALLEJA, GARCÍA DE PAREDES, GASPAR, SOR $Y$ TOBIO continued producing their contributions on the

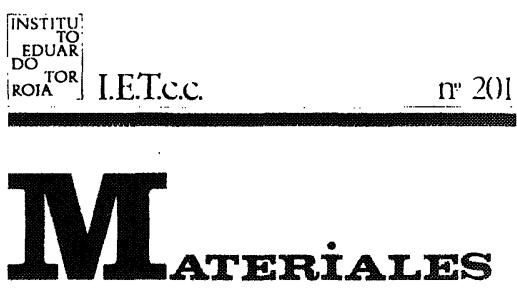

$\mathbf{D E}$

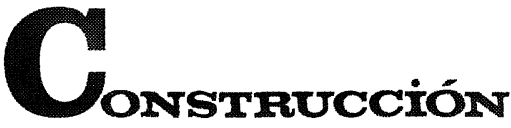

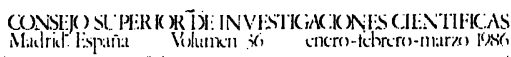

Figura 8.

Figure 8 . 
GARCÍADEPAREDES, GASPAR, SORIA y TOBIO, sobre los temas de los que cada uno se iba ocupando en cada momento. Analíticos: determinación del contenido de cemento en hormigones; métodos complexométricos para el análisis rápido del cemento portland. De Durabilidad: cuestiones sobre expansión en la teoría y en la práctica; resistencia del hormigón frente a sulfatos. Sobre Métodos de Ensayo: ensayos acelerados de resistencia del cemento; métodos para la determinación de la durabilidad de los cementos. Sobre cuestiones diversas: tratamientos térmicos del hormigón; microscopía del clínker; meteorización del cemento; corrosión interna de la envolvente de los hornos cementeros; estado actual (entonces) de los aditivos para hormigón; cuestiones que plantea el empelo del cemento; la resistencia de los morteros a las sales de magnesio; la aplicación de las técnicas de difracción de rayos $\mathrm{X}$ (DRX), espectroscopía infrarroja (IR) y análisis térmico (AT) al estudio del cemento; los sulfuros solubles en ácidos; entre otros.

Una segunda "generación", constituída por Bernardo BACLE, José Luis CEBRIÁN, César DĘL OLMO, Olga FERNÁNDEZPEÑA, José ManuelFERNÁNDEZ PARÍS, José Luis SAGRERA, Fernando TRIVIÑOy Tomás VÁZQUEZ aparecieron ya en el bloque de los segundos cien números de la Revista, colaborando con los "pioneros" unas veces, y a título individual otras, como publicistas de artículos sobre algunos de los temas ya señalados, o de otros tales como: la finura y superficie específica de compuestos anhidros e hidratados del cemento; la carbonatación del hormigón; la separación de fases aluminoferríticas en las pastas hidratadas; la dosificación de morteros y hormigones; la identificación de fases en el clínker; la formación de ettringita en el periodo plástico de la pasta de cemento; el ensayo de Le Chatelier-Anstett; la identificación y determinación del yeso en el cemento por análisis térmico; la hidratación del aluminato tricálcico en presencia de yeso...

Y una tercera "generación", más numerosa, empezaba ya a apuntar, con los nombres de M. C. ANDRADE, M.T.BLANCO, M.FRÍAS, S. GOÑI, M.P.LUXÁN, A.PALOMO, F.PUERTAS, M.I. SÁNCHEZDEROJAS, R. TALERO..., encabezando una lista que después se ha ido incrementando con que sé yo cuántos nombres más. Pero esto es ya "historia contemporánea" en la que me he propuesto no adentrarme, sino simplemente mencionarla en lo que sigue.

\section{HISTORIA CONTEMPORÁNEA}

De ésta sólo voy a mencionar los logros alcanzados hasta el momento presente por la Revista "MATERIALES DECONSTRUCCIÓN". Abro subjects each one specialized. Analytic:

determination of cement content in concrete, complexometric; methods for a quick analysis of portland cement,-. Durability: theory and practice of expansion; concrete capability to withstand sulfates attack. Test methods: accelerated test of cement strength. And a variety of other questions: thermal treatment of concrete; clinker microscopy; meteoric alterations of cement; inner corrosion of the coating of cement kilns; present situation (at that time) of admixtures for concrete; questions the use of cement raises; mortar strength against magnesium salt; applied $X$ ray diffraction techniques (XRD), infrared spectroscopy (IR) and thermal analysis for the study of cement; acid soluble suphides; among others.

A second "generation", with Bernardo BACLE, José Luis CEBRIÁN, Cesar DEL OLMO, Olga FERNÁNDEZ PEÑA, José Manuel FERNÁNDEZ PARÍS, José Luis SAGRERA, Fernando TRIVIÑO y Tomás VÁZQUEZ within this second cycle, have worked sometimes jointly with the "pioneers", sometimes independently, publishing articles on any of the subjects stated, or other subjects like: fineness and specific surface of anhydrous and hydrated cement compounds; concrete carbonation; removal of alumino-ferritic phases in hydrated pastes; mortars and concretes proportioning; identification of clinker phases; Ettringite formation during the plastic period of the cement paste; Le ChatelierAnstett test; identification and determination of gypsum in cement through thermal analysis; hydration of tri-calcium aluminate in the presence of gypsum...

But a third larger "generation" has already emerged. Their names: $M$. C. ANDRADE, M. T. BLANCO, M. FRÍAS,S. GOÑI, M. P. LUXÁN, A. PALOMO, F. PUERTAS, M. I. SÁNCHEZ DE ROJAS, R. TALERO..., are on the top of a list that is being increased with such and such new names. But yet, this is "contemporary history" that I intend not to dig into but just to mention it.

\section{CONTEMPORARY HISTORY}

From this epoch I only want to recall how many goals the Journal "MATERIALES DE CONSTRUCCIÓN" 
paréntesis para felicitar a quien o quienes tuvieron en su momento la feliz idea de suprimir el pretencioso pretítulo primero y posttítulo después de "ÚLTIMOS AVANCES".

Los logros a los que aludo se refieren al reconocimiento de la Revista por parte de diversas bases de datos y a su difusión en las mismas. Así, por ejemplo, es un hecho que los artículos publicados en ella son recogidos por las fuentes de mayor prestigio en cuanto a citación científica y tecnológica se refiere, como son, entre otras:

ANALYTICALABSTRACTS,BIOTECHNOLOGY ABSTRACTS,CERAMICABSTRACTS, CHEMICALABSTRACTS, ENERGY SCIENCE\& TECHNOLOGY y ENGINEERING. Además, a partir de 1996 los contenidos de la Revista son tomados en consideración por MATERIAL SCIENCE

CITATION INDEX, RESEARCH ALERT ${ }^{\circledR} \mathrm{y}$

SCISearch $^{\circledR}$.

\section{Y desde 1998 "MATERIALES DE}

CONSTRUCCIÓN" aparece también en las listas del JOURNALCITATIONREPORTS (JCR), base de datos elaborada por el INSTITUTE FOR SCIENTIFIC INFORMATION (151). Listas en las que se recogen, tanto el número de citaciones de la Revista en otras de su misma "especie" científica y técnica, como su evaluación comparativa a través de su "índice de impacto". La mencionada base de datos es la utilizada por autoridades académicas para valorar la calidad de las publicaciones en oposiciones, promociones, etc., a efectos de comparación de expedientes e historiales académicos y profesionales.

\section{EPÍTOME}

Se ha echado una amplia ojeada retrospectiva a las distintas etapas "históricas" de la Revista "MATERIALES DE CONSTRUCCIÓN"-nombre ¿último? de la misma- con espíritu analítico y crítico. Han salido a relucir aspectos positivos y negativos en su devenir, con avances y recesiones, pero siempre con una resultante final de mejora y progreso, desde la tirada en multicopista, sin figuras, sin... hasta las consecuciones acabadas de exponer en el punto precedente. Se han hecho destacar cambios en formatos y presentaciones, así como en orientación, todo lo cual ha redundado en mejoras sucesivas, a veces tardas en ser alcanzadas por mor de la inercia, pero logradas al cabo. Se ha llegado a donde ahora se está y dado que las metas conseguidas hay que pensar que lo han sido con carácter irreversible, no cabe sino esperar la arribada a muchas otras nuevas. congratulate the person who had the good idea of suppressing the pretentious pre-title at first, and then post-title of "LAST ADVANCES".

One of the goals reached is the recognition by several databases and its diffusion through them. In fact, articles the Journal publishes are mentioned in the most prestigious sources dedicated to scientific and technical citation, among others: ANALYTICAL ABSTRACTS, BIOTECHNOLOGYABSTRACTS, CERAMICABSTRACTS, CHEMICALABSTRACTS, ENERGY, SCIENCE \& TECHNOLOGY, and ENGINEERING. Moreover, from 1996 contents of our Journal are under consideration of MATERIAL SCIENCE CITATIONINDEX, RESEARCHALERT ${ }^{\circledR}$ and SCISearch $^{\circledR}$.

Since 1998 "MATERIALES DE CONSTRUCCIÓN" also appears on the lists of JOURNAL CITATION REPORTS (JCR), a database prepared by the INSTITUTE FOR SCIENTIFICINFORMATION(151).

Here are listed not only the times the Journal has been cited in other journals the of the same scientific and technical "kind", but also its comparative evaluation through the "impact index". The mentioned database is used by academic authorities to evaluate the quality of publications in exams, promotions, etc., in order to compare academic and professional career description and history.

\section{EPITOME}

This has been a wide retrospective of the different "historical" stages of the Journal "MATERIALES DE CONSTRUCCIÓN" -its last name?- written with analytic and critical criteria. Positive as well as negative aspects have been disclosed through its trajectory, with a final result of improvement and progress, from issues made using a duplicator machine, with no figures, no until reaching all that has just been described. Changes of format and of presentation, and orientation as well resulted in successive improvements, sometimes slow to accomplish on account of some inertia, but accomplished at last. We got what we have now and since goals attained are irreversible, we hope for the arrival at new ones. 
Quede para otros, si ha de ser así, la reseña, recensión y glosa del contenido, desarrollo y vicisitudes de sucesivos centenares de números de la Revista, que larga vida haya.
For years to come, other will replace us in the task of writing notices, information and reflections on the content, evolution and vicissitudes of thme successive hundreds of issues of the Journal. Long life to it.

\section{BIBLIOGRAFÍA}

(1) Calleja, J.: "Cincuenta Años de Desarrollo y Evolución del Cemento en España" Cemento-Hormigón, N 546 . (Extraordinario del 50 Aniversario de la Revista), mayo 1979, págs. 439-489, 1979.

(2) Calleja, J.: "Evocaciones de Aniversarios y Fechas para la Historia del Cemento en España”. Cemento-Hormigón (en preparación).

NOTE:

"The author is aware that the Spanish text of his contribution to this celebration, written especially for Spanish readers, does not uses the current language of scientific or technical papers, but another one more "literary" or even more colloquial, in any case much more difficult to translate into English. So, the translator thinks that the present translation could have missed the subtle, humorans and emotional concern the author pours in his writing. Nevertheless the author states that fully agrees with the translation and sincerely thanks the translator for it." 